\title{
LARGE SCALE SHORELINE PROTECTION WITH MINIMIZED DOWNDRIFT IMPACT, COTONOU, WEST AFRICA
}

\author{
Mohammad Dibajnia, Baird \& Associates, mdibajnia@baird.com \\ Dave Anglin, Baird \& Associates, danglin@baird.com \\ Rob Nairn, Baird \& Associates, rnairn@baird.com
}

\section{INTRODUCTION}

Benin is a country in West Africa with a little more than 120 kilometers of coastline. The main port at Cotonou serving the country of Benin was completed in 1963. According to Dibajnia and Nairn (2004), Benin's coastline experiences incessant wave attack causing a longshore sand transport rate in the order of 1 million $\mathrm{m}^{3}$ per year (moving from west to east). The port facility initially blocked the full amount of sand transported along the shore, resulting in accumulation of a large beach on the updrift (west) side of the port and corresponding dramatic erosion of the downdrift (east) shoreline consisting of over $400 \mathrm{~m}$ of shoreline retreat by 2003 (i.e. over approximately 40 years). Additionally, since 1998 sand started to bypass around the harbor breakwater into the entrance channel. Harbor entrance channel dredging requirements was escalating with almost 1.5 million $\mathrm{m}^{3}$ dredged between 1998 and 2002 . At the time of port construction, the downdrift erosion was not a concern as the area was largely undeveloped. However, with the inevitable expansion of the city of Cotonou towards the east, the ongoing erosion started to destroy newly developed residential and commercial areas.

\section{DESIGN}

Baird \& Associates were retained by Canadian consulting firm Roche (now Norda Stelo) to conduct an integrated study and complete design development for solutions to the harbor sedimentation and downdrift erosion problems. An extensive set of investigations, including hydrographic and topographic surveys, longterm wave climate hindcast, sediment sampling, nearshore profile surveys, boreholes, GIS analysis of historic air photos and recent satellite images, geomorphic assessment, and comprehensive 1D (profile) and 2DH (depth-averaged) numerical modeling of hydrodynamics and sediment transport were undertaken to understand details of the ongoing coastal processes, establish an accurate sediment budget and assess alternative solutions to the erosion problem. An important objective was to halt the long-term trend of shoreline retreat at the minimum possible cost and minimize or eliminate the requirement for initial and future beach nourishment to maintain the integrity of the sea defense project (due to financing concerns).

The final design to address harbor sedimentation involved a $300 \mathrm{~m}$ extension to an existing jetty at the port. The final design to address downdrift erosion involved the reconstruction of an existing jetty (Epi Est) along a new alignment and construction of seven new headland structures spaced approximately $1 \mathrm{~km}$ apart along the shoreline downdrift of Epi Est as shown in Figure 1.

\section{CONSTRUCTION}

Construction of the port improvements were completed in 2009-2011. Construction of the headland system was completed by Boskalis in 2012-2014, with Norda Stelo providing construction oversight. The project received a Canadian Consulting Engineering Award of Excellence in November 2016.

\section{SHORELINE RESPONSE}

A review of shoreline response after the construction of the project, including the project impact on the shoreline downdrift of Headland 7 is provided in the following. Note that approximately a decade elapsed between design and construction during which the downdrift shoreline continued to erode back up to about $100 \mathrm{~m}$. See Figure 3 as an example.

Headland1 has a complex planform with a total length of approximately $200 \mathrm{~m}$ as shown in Figure 2. Design and as-built locations do not match due to shoreline erosion prior to the start of construction. Beach nourishment using material dredged from the port was recommended for the pocket beach between the New Epi Est and Headland 1 (shown by the yellow line in Figure 2). However, this was not materialized. The curved shape of this headland was to minimize sediment bypassing and stabilize the pocket beach.

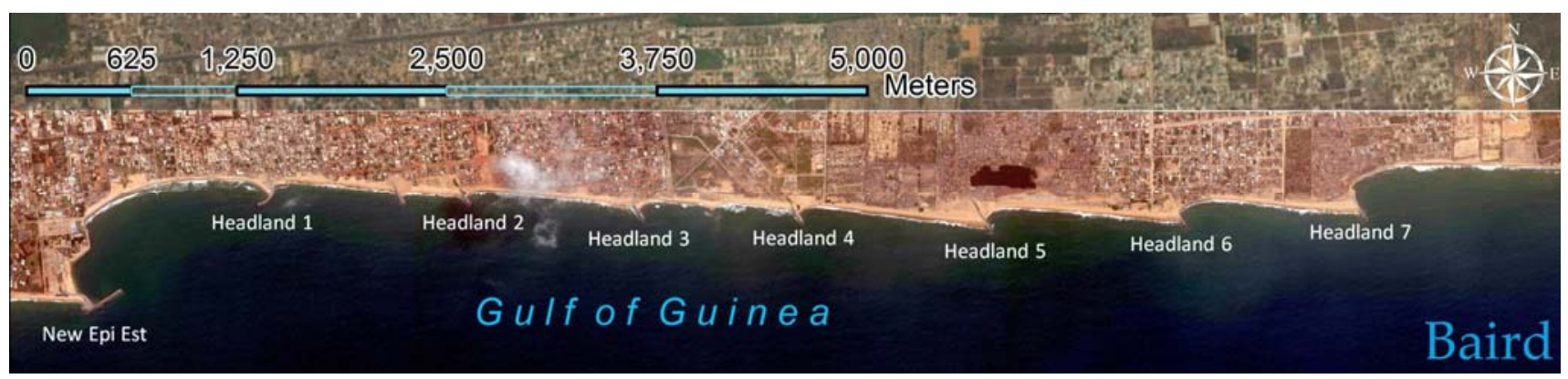

Figure 1 - Overall project conditions in April 2018 


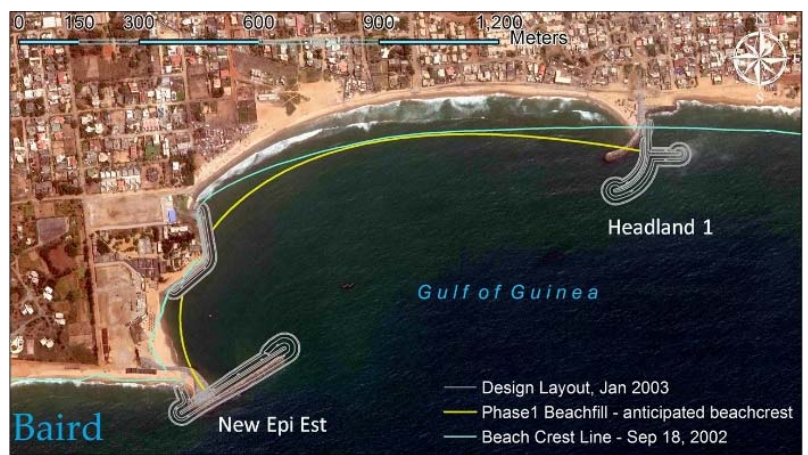

Figure 2 - Conditions of pocket beach between Epi Est and Headland 1 in April 2018

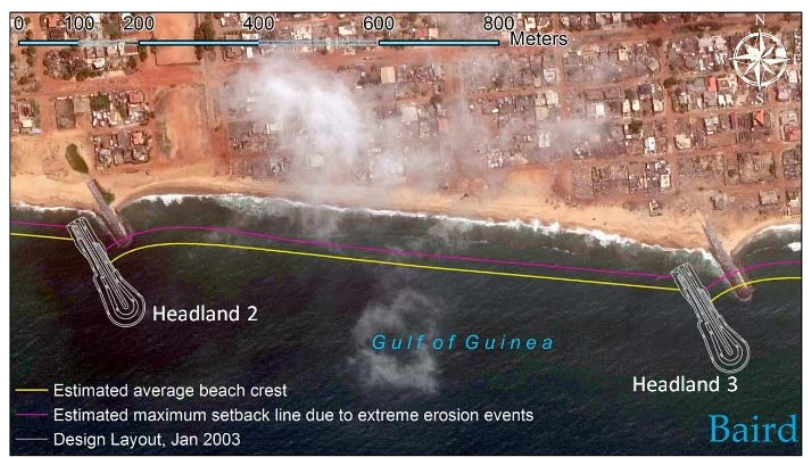

Figure 3 - Design vs. constructed Headlands 2 and 3 locations. The shoreline eroded approximately $100 \mathrm{~m}$ between completion of design and start of construction

The headland structures (Headlands 2 to 7 ) extend into a water depth of approximately $-4 \mathrm{~m} \mathrm{CD}$. The headlands were designed to be straight and oriented approximately 30 degrees downdrift of the shore-normal. They also extend approximately $30 \mathrm{~m}$ back behind the beach berm in order to reduce the risk of flanking erosion on the downdrift side of the structures as the beach planform naturally adjusts to reach the new equilibrium shape. The proposed setback together with the 30-degree alignment were intended to minimize the trapping capacity of the headlands and maximize the potential for sand bypassing thus minimizing downdrift erosion impacts.

Sample comparisons of shoreline response with design predictions using Hsu and Evans (1989) method at two locations are provided in Figure 4 and Figure 5. Design lines were shifted to match as-built locations. The yellow line in these figures represents the predicted average beach crest/berm line. In both cases the shoreline has responded in reasonable agreement with the predictions. The pink line in these figures represents potential extreme erosion events and was used to define erosion setbacks.

Figure 6 compares shoreline conditions downdrift of Headland 7 in April 2018, i.e. approximately five years after completion of the project, with 10-year and 20 -year predicted erosion lines. The beach crestline around the time of construction (2013) is also shown in this figure. Overall downdrift erosion has progressed in a slightly slower pace than predicted. While this could be due to variations in annual wave climate, it still indicates that the headland system designed with setback and 30degree alignment has optimized sand trapping thus minimizing downdrift erosion.

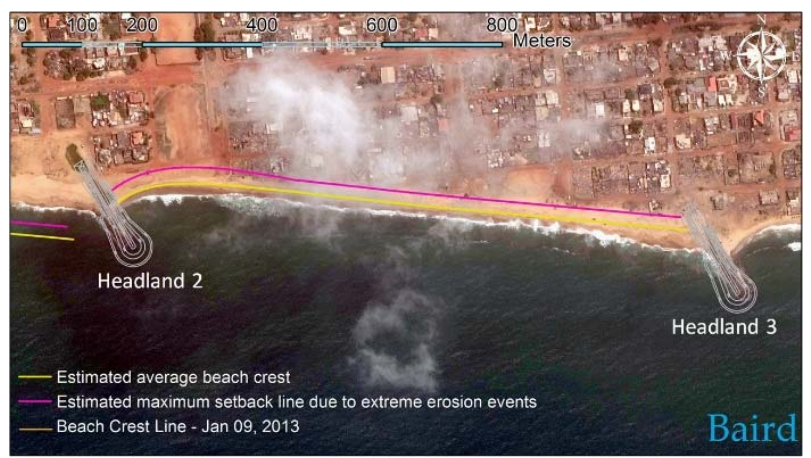

Figure 4 - Predicted average and post-storm beach crest line on the 2018 satellite image (Headlands 2 and 3)

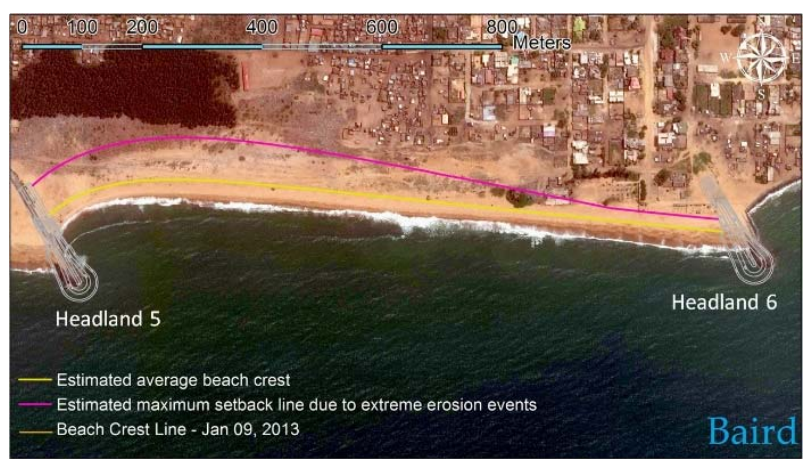

Figure 5 - Predicted average and post-storm beach crest lines on the 2018 satellite image (Headlands 5 and 6)

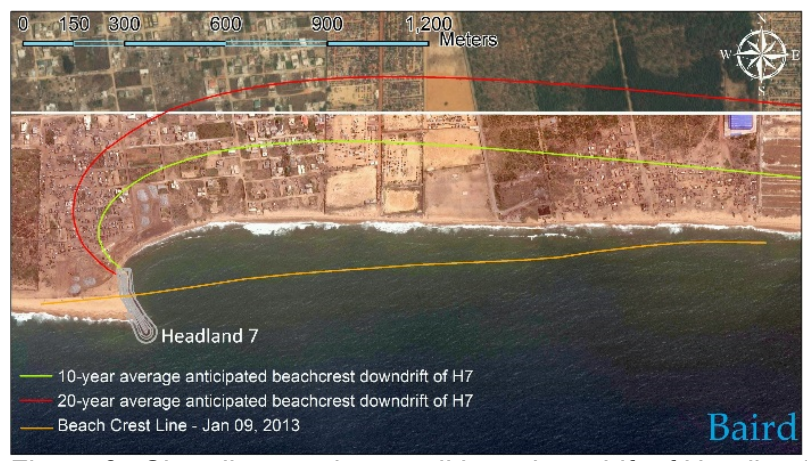

Figure 6 - Shoreline erosion conditions downdrift of Headland 7 in April 2018 vs. 10-year and 20-year predictions.

\section{REFERENCES}

Dibajnia and Nairn (2004): Cotonou sea defence project, Benin, West Africa, Proc. 29th Int. Conf. on Coastal Eng., ASCE, pp. 3927-3939.

Hsu and Evans (1989). Parabolic bay shapes and applications. Proc. of the Institution of Civil Engineers, 87 (2): 557-570. 